\title{
Kebijakan Penerbitan Kartu Identitas Anak di Kota Semarang
}

\author{
Untung Sri Hardjanto \\ Fakultas Hukum, Universitas Diponegoro \\ Email: sri nurhari60@yahoo.co.id
}

\begin{abstract}
The study aims to determine the policy of publishing identity cards for children in Semarang. The method of approach taken in this study is normative juridical. Data collection is obtained from the results of interviews and through library research. The data analysis method used is a qualitative descriptive analysis method. The results showed that the Regional Government of Semarang City in carrying out KIA issuance made PERDA No.4 of 2016, but its implementation was in 2017. Delay in the implementation of $\mathrm{MCH}$ due to the lack of coverage of ownership of birth certificates for children. The preparations made by the Semarang City Government in the context of the implementation of the $\mathrm{MCH}$ in 2017 are collecting data on children, discussing the additional benefits of KIA with several official agencies and the private sector, conducting comparative studies in regions that have implemented KIA and the basis of its arrangements. Preparation of the Regional Government of Semarang City in the issuance of KIA experienced several obstacles, among others, the unclear distribution of KIA forms, limitations and delays in budgeting, lack of competent human resources for the operation of SIAK. For ITU, the Semarang City Government made an effort to procure KIA sheets themselves, prepare computerized system training or SIAK, and make Mayor Regulations as technical implementation of Regional Regulation No.4 of 2016 concerning Implementation of Population Administration.
\end{abstract}

Keywords: Child Identity Card, Policy, City of Semarang

\begin{abstract}
Abstrak
Penelitian bertujuan untuk mengetahui kebijakan penerbitan kartu identitas anak di kota semarang. Metode pendekatan yang dilakukan dalam penelitian ini adalah yuridis normatif, Pengumpulan data diperoleh dari hasil wawancara dan melalui penelitian kepustakaan. Metode analisis data yang digunakan adalah metode analisa deskriptif kualitatif. Hasil penelitian menunjukkan bahwa Pemerintah Daerah Kota Semarang dalam melaksanakan penerbitan KIA membuat PERDA No.4 Tahun 2016, namun pelaksanaannya pada tahun 2017. Keterlambatan pelaksanaan KIA karena masalah cakupan kepemilikan Akta Kelahiran anak yang masih kurang. Persiapan yang dilakukan Pemda Kota Semarang dalam rangka pelaksanaan KIA di tahun 2017 adalah mengumpulkan data anak-anak, membahas penambahan manfaat KIA dengan beberapa pihak dinas dan pihak swasta, melakukan studi banding ke daerah yang sudah melaksanakan
\end{abstract}


KIA dan dasar pengaturannya. Persiapan Pemda Kota Semarang dalam penerbitan KIA mengalami beberapa kendala antara lain ketidakjelasan pendistribusian blanko KIA, keterbatasan dan keterlambatan pemberian anggaran, kurangnya sumber daya manusia yang kompeten untuk pengoperasian SIAK. Untuk ITU Pemda Kota Semarang melakukan upaya yakni pengadaan blanko KIA sendiri, mempersiapkan pelatihan sistem komputerisasi atau SIAK, dan membuat Peraturan Walikota sebagai pelaksanaan teknis dari Perda No.4 Tahun 2016 Tentang Penyelenggaraan Administrasi Kependudukan.

Kata Kunci: Kartu Identitas Anak, Kebijakan, Kota Semarang

\section{A. Pendahuluan}

Setiap Warga Negara Indonesia (WNI) yang telah berumur 17 tahun atau telah kawin atau pernah kawin wajib memiliki KTP-el sesuai dengan ketentuan dalam Pasal 63 ayat (1) Undang-Undang Nomor 24 Tahun2013 Tentang Perubahan Atas Undang-Undang Republik Indonesia Nomor 23 Tahun 2006 tentang Administrasi Kependudukan. Untuk membuat KTP-el penduduk yang bersangkutan dapat mengurusnya langsung kepada Instansi Pelaksana melalui Kecamatan/Kelurahan dimana penduduk tinggal. Fungsi KTP-el sendiri antara lain adalah sebagai identitas jati diri bagi pemiliknya. Kerugian yang akan dialami jika tidak memiliki identitas antara lain adalah kesulitan untuk mendapatkan pelayanan public secara maksimal, tidak bisa membuat rekening bank, tidak mempunyai identitas legal sehingga akan sulit untuk melakukan aktifitas baik didalam maupun diluar negeri, dan masih banyak hal lain yang mensyaratkan adanya suatu identitas.

Pasal 27 ayat (1) dan (2) Undang-Undang Nomor 35 Tahun 2014 tentang Perlindungan Anak menyatakan bahwa "identitas diri setiap anak harus diberikan sejak kelahirannya" dan "identitas" sebagaimana yang dimaksud pada ayat (1) dituangkan dalam Akta Kelahiran. Pengertian Akta Kelahiran sendiri adalah sebuah akta yang wujudnya selembar kertas yang dikeluarkan Negara berisi informasi mengenai identitas anak yang dilahirkan yaitu berupa nama, tempat tanggal lahir, nama orang tua, serta tanda tangan pejabat yang berwenang. ${ }^{1}$ Kebijakan Penerbitan Kartu Identitas Anak karena Akte Kelahiran yang dimiliki oleh seorang anak tidaklah cukup, karena pada dasarnya akte kelahiran yang diterbitkan hanya memberikan status kepada anak. Akta Kelahiran hanya menunjukkan

\footnotetext{
${ }^{1}$ Srinurbayanti Herni, Rofiandi Ronal, dan Novitarini Wini, Publikasi Hak Masyarakat Dalam Bidang Identitas Cet 2, Pusat Studi Hukum dan Kebijakan Indonesia, Jakarta, 2003, hlm 19
} 
keabsahan legalitas seseorang dan menunjukkan kewarganegaraan seseorang ${ }^{2}$. Identitas seseorang dapat dibuktikan salah satunya dengan kartu identitas, tetapi pada saat ini nyatanya anak-anak dibawah usia 17 tahun belum memiliki kartu identitas yang berlaku secara nasional dan terintegrasi dengan Sistem Informasi Administrasi Kependudukan (SIAK).

Deklarasi Universal Hak Asasi Manusia Tahun 1948 (Declaration of Human Rights) Pasal 25 ayat 2 menyatakan bahwa semua anak, baik yang lahir di dalam maupun di luar perkawinan harus mendapat perlindungan social yang sama. Berdasarkan pada ketentuan tersebut maka seharusnya anak-anak berusia dibawah 17 tahun juga memiliki Kartu Identitas yang berlaku sama dengan KTP-el guna melindungi hak identitas nya dan juga mendapatkan pelayanan public secara maksimal.

Sudah menjadi kewajiban pemerintah untuk memberikan identitas kependudukan kepada seluruh penduduk yang berlaku secara nasional sebagai upaya perlindungan dan pemenuhan hak konstitusional warga Negara dalam rangka meningkatkan kesejahteraan masyarakat. ${ }^{3}$ Oleh karena itu kebijakan pemerintah ini dimaksudkan sebagai upaya pemerintah dalam memberikan dan melindungi hak anak, identitas diwujudkan dengan program Penerbitan Kartu Identitas Anak (KIA) yang mulai berlaku sejak awal tahun 2016 lalu. Kebijakan Nasional mengenai penerbitan KIA ini diatur didalam Peraturan Menteri Dalam Negeri Nomor 2 Tahun 2016 tentang Kartu Identitas Anak. Kebijakan ini dikeluarkan sebagai salah satu peraturan pelaksana dari UU Adminduk. Permendagri ini mengatur mengenai hal-hal yang berkaitan dengan KIA seperti syarat-syarat untuk mendapakan KIA , prosedur untuk mendapatkan KIA, elemen yang tercantum di KIA dan sebagainya.

Tujuan penerbitan Kebijakan KIA yang dimuat dalam Permendagri adalah untuk mendorong peningkatan pendataan, perlindungan dan pelayanan public untuk mewujudkan hak terbaik bagi anak, maka dilakukan pemberian identitas kependudukan pada anak. Selain itu peraturan ini juga diterbitkan sebagai bentuk kewajiban pemerintah untuk memberikan identitas kependudukan kepada seluruh penduduknya yang berlaku secara nasional. Orang tua dapat mengajukan permohonan penerbitan KIA bagi anaknya dalam rangka pendataan, perlindungan dan pelayanan public untuk mewujudkan hak terbaik bagi anak itu sendiri.

\footnotetext{
${ }^{2}$ Elina Aryanti, “ Implementasi Kebijakan Kependudukan di Kabupaten Kuantan Singingi (Studi Kasus Pengurusan Akta Kelahiran Tahun 2012)” Dalam Jurnal Online Mahasiswa FISIP Volume 1 No.2-Oktober 2014, halaman 4

3 Lijan Poltak Sinambela,dkk.,Reformasi Pelayanan Publik: Teori,Kebijakan dan Implementasi ,PT.Bumi Aksara,Jakarta,2006, halaman 5
} 
Pelaksanaan kebijakan penerbitan Kartu Identitas Anak di Indonesia dimulai di Kota Cimahi. Kementrian Dalam Negeri Republik Indonesia melalui Direktorat Jendral Kepndudukan melakukan pelaksanaan awal KIA karena tingkat kecakupan Akte Kelahiran Anak di Cimahi mencapai 67.5\%. Kota Cimahi merupakan satu-satunya kabupaten/kota di Jawa Barat sekaligus salah satu dari kabupaten/kota di Indonesia yang menjadi daerah percontohan dalam pembuatan KIA untuk sekitar 185 ribu anak. Sementara itu komposisi penduduk Kota Semarang pada tahun 2016 jumlahnya 1,634,482 jiwa, dan dari jumlah tersebut sebanyak 447,854 merupakan penduduk anak-anak yang berusia 1-16 tahun. Dengan banyaknya jumlah anak yang ada di Kota Semarang maka Pemerintah Kota Semarang perlu mengambil kebijakan penerbitan KIA dalam rangka melakukan perlindungan terhadap anakanak tersebut. Untuk itu akan dilihat lebih lanjut bagaimana upaya-apaya yang diambil rangka penerbitan KIA di Kota Semarang serta upaya yang dilakukan untuk mengatasi kendala yang muncul?

Untuk mendapatkan gambaran mengenai kebijakan yang dilakukan Pemerintah Daerah Kota Semarang maka dilakukan penelitian dengan pendekatan yuridis normatif,spesifikasi penelitian deskriptif analitis serta metode pengumpulan data dengan studi pustaka,wawancara berakhir dengan simpulan dengan metode analisa kualitatf.

\section{B. Pembahasan}

\section{Kebijakan Administrasi Kependudukan}

Menurut pasal 1 No 24 Tahun 2013 tentang Perubahan atas Undang-Undang Nomor 23 Tahun 2006 Tentang Administrasi Kependudukan yang dimaksud dengan Administrasi Kependudukan adalah rangkaian kegiatan penataan dan penertiban dalam penerbitan dokumen dan Data Kependudukan melalui Pendaftaran Penduduk, Pencatatan Sipil, Pengelolaan Informasi Administrasi Kependudukan serta Pendayagunaan hasilnya untuk Pelayanan publik dan pembangunan sektor lain.

Ruang lingkup administrasi kependudukan meliputi 3 (tiga) komponen :

1) Kegiatan penataan dan penertiban dokumen dan data kependudukan melalui pendaftaran penduduk

2) Kegiatan penataan dan penertiban dalam penertiban dokumen dan data kependudukan melalui pencatatan sipil dan 
3) Kegiatan pentaan dan penertiban dalam penerbitan dokumen data kependudukan melalui data pengelolaan informasi administrasi kependudukan serta pendayagunaan hasilnya untuk pelayanan publik dan pembangunan sektor lain. ${ }^{4}$

Administrasi kependudukan dapat membantu pemerintah dalam mencatat dan mengelola setiap peristiwa penting dan/atau peristiwa kependudukan yang terjadi sehingga menghasilkan data kependudukan yang lebih akurat, lengkap, dan tersusun rapih, dalam upaya untuk mewujudkan kesejahteraan masyarakat dan membantu pemerintah untuk memenuhi kebutuhan masyarakat dalam rangka manfaat pelayanan publik.

Sebagi upaya mendukung pelaksanaan penyelenggaraan Administrasi Kependudukan yang lebih canggih, tersusun dengan rapih dan akurat serta unuk mmpermudah akses secara nasional maka kemudian diterapkan Sistem Informasi Administrasi Kependudukan (SIAK). SIAK adalah suatu sistem informasi yang disusun berdasarkan prosedur-prosedur bebasis teknologi informasi dan komunikasi yang bertujuan untuk menata sistem administrasi kependudukan di Indonesia, sistem ini meliputi pendataan penduduk dan pencataatn sipil. ${ }^{5}$

Sistem informasi Administrasi Kependudukan dimaksudkan untuk :

1) Terselenggaranya Administrasi Kependudukan dalam skala nasional yang terpadu dan tertib

2) Terselenggaranya Administrasi Kependudukan yang bersifat universal, permanen, wajib dan berkelanjutan.

3) Terpenuhinya hak Penduduk di bidang Administrasi Kependudukan dengan pelayanan yang professional, dan

4) Tersedianya data dan informasi secara nasional mengenai Pendaftaran Penduduk dan Pencatatan Sipil pada berbagai tingkatan secara akurat, lengkap, mutakhir, dan mudah diakses sehingga menjadi acuan bagi perumusan kebijakan dan pembangunan pada umumnya.

\footnotetext{
${ }^{4}$ Tim Pengkajian Sistem Pelayanan Administrasi Kependudukan, “ Rumusan Rapat Koordinasi Kependudukan Pengkajian Sistem Pelayanan Administrasi Kependudukan, Jakarta, 29 Mei 2002.

5 Diakses dari https://id.wikipedia.org/wiki/Sistem_informasi_administrasi_kependudukan pada 17 Februari 2017 pukul 16.42
} 
Administrasi Kependudukan ini sifatnya sangat penting tetapi pada beberapa daerah hal ini belum ditindaklanjuti, khususnya dalam penyelenggaraan pemerintahan, baik dalam perencanaan, penerapan maupun evaluasi kebijakan daerah. Beberapa penyebabnya adalah:

a. Masih banyaknya aparat pemerintah daerah khususnya aparat provinsi, kabupaten dan kota yang belum memahami kebijakan administrasi kependudukan secara benar sehingga timbul anggapan bahwa kebijakan administrasi kependudukan bukan kebijakan yang menjadi prioritas pemerintah daerah melainkan kebijakan pemerintah pusat ;

b. Kebijakan administrasi kependudukan tidak masuk dalam perencanaan (anggaran) pembangunan daerah karena kurangnya pemahaman;

c. Kebijakan administrasi kependudukan sebagai individu kesejahteraan tidak dijadikan sebagai unsur penilaian kinerja pemerintah daerah sehingga administrasi kependudukan tidak dijadikan salah satu indikator keberhasilan kepala daerah. Kondisi demikian, menjadikan administrasi kependudukan cenderung diabaikan oleh pemerintah daerah, DPRD maupun masyarakat.

d. Masih rendahnya kesadaran masyarakat tentang pentingnya dokumen kependudukan dalam menunjang aktivitasnya, sehingga kesadaran untuk mengurus atau memiliki dokumenkependudukan atas inisiatif sendiri masih rendah. ${ }^{6}$

\section{Pelaksanaan Peraturan Menteri Dalam Negeri Nomor 2 Tahun 2016 Tentang Kartu Identitas Anak di Kota Semarang}

Pada bab sebelumnya telah dijelaskan bahwa Pemerintah telah meratifikasi Konvensi Hak Anak, yang salah satu substansinya mengatur mengenai hak seorang anak untuk mendapatkan identitas diri. Untuk mendukung pelaksanaan tertib administrasi identitas diri, Pemerintah juga telah menetapkan Undang-Undang Nomor 23 Tahun 2006 tentang Administrasi Kependudukan (UU Adminduk). Didalam UU Adminduk, seseorang berhak mendapatkan identitas diri jika teha berusia 17 tahun, sedangkan anak cukup memperoleh akta kelahiran atau surat tanda kenal lahir.

\footnotetext{
${ }^{6}$ Tria Febrina, "Implementasi Kebijakan Kependudukan (Studi Kasus Peraturan Daerah Nomor 2 Tahun 2012 Tentang Retribusi Penggantian Biaya Cetak Kartu Tanda Penduduk dan Akte Catatan Sipil Tahun 2013)" Dalam Jurnal Online Mahasiswa Fisip Vol.2 No.1-Februari 2015, halaman 2
} 
Seiring dengan perkembangan waktu, Pemerintah menyadari bahwa anak juga memerlukan identitas diri. Untuk itu dilaksanakanlah Perintah Mentteri Dalam Negeri Nomor 2 Thun 2016 tentang Kartu Identitas Anak (KIA). Tujuannya untuk meningkatkan pendataan, perlindungan, dan pelayanan public serta upaya memberikan perlindungan dan pemenuhan hak konstitusional warga negara. ${ }^{7}$ Artinya bahwa Negara mempunyai tanggung jawab untuk memberikan perlindungan kepada anak sejak usia 0 bulan sampai sebelum usia 17 tahun. KIA sendiri diberikan kepada :

1. Bagi anak yang berusia dibawah 5 tahun bersamaan dengan penerbitan kutipan akta kelahiran;

2. Anak usia 5 tahun sampai dengan 17 tahun kurang satu hari;

3. Anak WNI yang baru dating dari luar negeri

Ketiga alasan inilah yang menjadi dasar bagi Pemerintah, bahwa anak harus memperoleh kartu identitas diri.

Peraturan Menteri Dalam Negeri No 2 Tahun 2016 rentang Kartu Identitas Anak ini diundangkan pada tanggal 19 Januari 2016. Permendagri ini diterbitkan berdasarkan amanat Undang Undang Nomor 23 Tahun 20016 tentang Administrasi Kependudukan sebagaimana terakhir diubah dengan Undang-Undang Nomor 24 Tahun 2013 tentang Perubahan Atas UU NO 23 Tahun 2006 tentang Administrasi Kependudukan.

Didalam penjelasan umum Undang-Undang tersebut menjelaskan bahwa Nomor Induk Kependudukan (NIK) adalah identitas penduduk Indonesia dan merupakan kunci akses untuk melakukan verifikasi dan validasi data jati diri seseorang guna mendukung pelayanan publik di bidang Administrasi Kependudukan. Salah satu elemen yang tercantum didalam KIA adalah NIK, sementara Akta Kelahiran tidak mencantumkan NIK seseorang sehingga KIA dapat memberikan identitas bagi pemiliknya. Selain itu adanya identitas juga memberikan pengakuan terhadap jati diri sesorang sehingga KIA itu penting sebagaimana tercantum dalam Undang-Undang Dasar 1945 Pasal 28D ayat 1 yang menyatakan bahwa setiap orang berhak atas pengakuan, jaminan, perlindungan, dan kepastian hokum yang adil serta perlakuan yang sama dihadapan hokum. Untuk mendukung terselenggaranya pelaksanaan KIA di Kota Semarang, Pemerintah Kota Semarang telah menerbitkan Peraturan Daerah No.4 Tahun 2016 tentang

${ }^{7}$ Ketentuan Pasal 2 Permendagri Nomor 2 Tahun 2016 tentang Kartu Identitas Anak 
Penyelenggaraan Administrasi Kependudukan yang diundangkan tanggal 12 Agustus 2016 sekaligus sebagai pengganti PERDA Kota Semarang No. 2 Tahun 2008 tentang Penyelenggaraan Administrasi Kependudukan dalam PERDA Kota Semarang rentang Penyelenggaraan Administrasi Kependudukan yang baru telah mengatur mengenai KIA. Pasal 62 ayat (1) menunjukan bahwa KIA merupakan salah satu dokumen kependudukan.

Hal mengenai KIA dalam PERDA tersebut diatur dalam Pasal 68 dan 69. Menurut Pasal 68 ayat (1) penduduk WNI dan penduduk orang asing yang memiliki izin tinggal tetap yang berusia 17 tahun dan belum menikah wajib memiliki KIA. Dapat dikatakan bahwa peraturan mengenai KIA yang diatur didalam PERDA tersebut sesuai dengan apa yang diamanatkan dalam Permendagri No 2 Tahun 2016 tentang KIA. Meskipun sudah diundangkan pemerintah Kota Semarang belum mulai melaksanakan program KIA.

Berdasarkan penjelasan Bapak Hasto Himahono,S.H. selaku Kepala Bidang Pendaftaran Penduduk, beliau mengatakan bahwa keterlambatan dalam pelaksanaan program KIA ini dikarenakan Pemerintah Pusat menyatakan bahwa program KIA ini tidak diberlakukan secara serentak di seluruh wilayah di Indonesia. Pemerintah Pusat hanya mengamanatkan bahwa pemberian KIA ini diukur dari cakupan kepemilikan akta kelahiran. Artinya bagi daerah dengan kepemilikan akta kelahiran terbanyak adalah yang didahulukan menerbitkan KIA.

Menurut data Kependudukan Kota Semarang pada Tahun 2015/2016 presentase cakupan kepemilikan akta kelahiran hanya sebesar $70 \%$ sementara batasan minimal cakupan kepemilikan akta adalah $75 \%$. Berdasarkan data tersebut makan Pemerintah Kota Semarang belum segera untuk mencetak atau melakukan penerbitan KIA. Presentase $75 \%$ tersebut merupakan akta kelahiran keseluruhan yang dimiliki oleh anakanak saja. Namun demikian untuk mendukung pelaksanaan KIA di Kota Semarang, PEMDA tetap akan melaksanakan pemberian KIA di Kota Semarang tahun 2017.

Dalam Permendagri Nomor 2 Tahun 2016 tentang KIA menyatakan bahwa KIA diberikan kepada anak-anak anak usia 0-17 tahun kurang satu hari. Namun Kota Semarang akan memberikan KIA kepada anak-anak usia 0-15 tahun. Menurut Bapak Hasto " Karena bagi anak-anak yang berusia 16 tahun menuju 17 tahun KIA hanya dapat dipakai sebentar, dan selanjutnya mereka diharuskan untuk segera membuat KTP." 
Bapak Hasto juga menyatakan bahwa KIA ini bersifat wajib meskipun didalam PERDA tidak mencantumkan adanya sanksi administrative bagi keterlambatan pembuatan KIA atau bagi anak-anak yang tidak memiliki KIA.

Pelaksanaan pemberian KIA di Kota Semarang rencananya akan dilakukan dengan 3 (tiga) cara. Pertama, KIA diberikan bersamaan dengan pemberian Akta Kelahiran sehingga setiap pengajuan permohonan pencetakkan akta kelahiran bagi anak yang baru lahir akan sekaligus diberikan. KIA. Kedua, bagi anak-anak 6-17 tahun pihak Dispendukcapil Kota Semarang akan bekerja sama dengan Dinas Pendidikan yaitu dengan jemput bola dimana pemerintah bekerja sama dengan sekolah-sekolah untuk mendata muridnya yang sudah atau belum memiliki akta kelahiran dan untuk kemudian diberikan KIA. Ketiga, yaitu secara regular dimana masyarakat mengajukan permohonan secara umum ke Dispendukcapil Kota Semarang untuk membuat KIA.

Dalam rangka " pelayanan prima”, Kantor Dispendukcapil Kota Semarang juga membantu masyarakat dalam membuat KIA, dengan mempermudah persyaratan membuat KIA yaitu pengajuan untuk pembuatan KIA secara regular tidak harus dating langsung ke Kantor Dispendukcapil Kota Semarang melainkan dapat juga melalui Tempat Perekaman Data Kependudukan (TPDK) yang terdapat di setiap 16 kecamatan yang ada di Kota Semarang. Tujuan adanya TPDK ini adalah diharapkan dapat mendekatkan pemberian pelayanan kepada masyarakat. Namun, apabila bersifat insidentil Kantor Dispendukcapil pasti akan langsung melayani.

Syarat untuk pengajuan pembuatan KIA ini sangatlah mudah. Setiap anak hanya perlu membawa fotokopi Akta Kelahiran bagi yang sudah memiliki dan juga fotokopi Kartu Keluarga (KK) sebagai bukti yang menunjukan bahwa si anak sudah terdaftar dalam keluarga. Kemudian membawa foto bagi anak yang berusia 6-17 tahun, bagi anak usia 0-5 tahun KIA nya tidak menggunakan foto. Sementara bagi orang tua si anak hanya perlu menunjukkan KTP-el yang asli.

Tata cara pembuatan KIA diatur dalam Pasal 13 Permendagri No.2 Tahun 2016 tentang Kartu Identitas Anak, sebagai berikut : 1). Pemohon atau orangtua anak menyerahkan persyaratan penerbitan KIA dengan menyerahkan persyaratan ke Dinas Kependudukan dan Pencatatan Sipil (Dukcapil); 2). Kepala Dinas menandatangani dan menerbitkan KIA KIA dapat diberikan kepada pemohon atau orangtuanya di kantor 
Dinas atau kecamatan atau desa/kelurahan; 3). Dinas dapat menerbitkan KIA dalam pelayanan keliling dengan cara jemput bola di sekolah-sekolah, rumah sakit, taman bacaan, tempat hiburan anak-anak dan tempat layanan lainnya, agar cakupan kepemilikan KIA dapat maksimal.

Menurut Pasal 69 ayat (1) PERDA no. 4 Tahun 206 Tentang Penyelenggaraan Administrasi Kependudukan menyatakan bahwa KIA, memuat elemen data sebagai berikut : NIK; Nama; Jenis kelamin; Golongan darah; Tempat/tanggal lahir; Nomor kartu keluarga; Nama Kepala keluarga; Nomor Akta Kelahiran; Agama; Kewarganegaraan; Alamat; Masa berlaku; Tempat penerbitan; Nomenklatur dinas; Nama dan tanda tangan kepala dinas.

Jika dilihat dari apa yang tercantum didalam KIA maka dapat dikatakan bahwa meskipun KIA merupakan suatu kartu identitas tetapi KIA tidak hanya mencantumkan identitas saja tetapi juga status dari si pemilik KIA. Nantinya KIA ini akan diberikan kepada seluruh anak tanpa memandang anak tersebut bersekolah atau tidak. Selain itu KIA akan diberikan secara gratis tanpa pemungutan biaya apapun sehingga bagi masyarakat yang kurang mampu tetap bisa mengajukan pembuatan KIA bagi anak-anaknya. Selain sebagai pelindung identitas, KIA juga diharapkan dapat memberi manfaat antara lain seperti dapat digunakan untuk :

1. Mendaftar sekolah

2. Pembuatan dokumen keimigrasian

3. Mendaftar BPJS

4. Membuka tabungan/rekening di bank

5. Berobat di puskesmas atau rumah sakit

6. Proses identifikasi jenazah dengan korban anak-anak dan juga untuk mengurus klaim santunan kematian

7. Mempermudah proses pencarian anak hilang

8. Terhindarnya pemalsuan identitas anak

9. Melindungi anak yang berhadapan dengan hokum

10. Mencegah terjadinya illegal trafficking

11. Mencegah terjadinya perdagangan anak

12. Hal-hal pelayanan public lainnya yang membutuhkan bukti diri si anak 
Untuk mendukung pelaksanaan program KIA yang akan dilaksanakan pada tahun 2017 pemerintah sudah menyiapkan beberapa persiapan. Pertama pemerintah mencari dan mengumpulkan data dari anak-anak berusia 0-17 tahun di 16 Kecamatan di Kota Semarang. Data-data tersebut antara lain data jumlah penduduk Kota Semarang. Data tersebut antara lain data jumlah penduduk Kota Semarang berusia 1-16 tahun dan data kepemilikan akta kelahiran bagi usia 0-18 tahun. Data tersebut digunakan untuk mempermudah dalam mengetahui seberapa banyak anak-anak yang dicetakan KIA nantinya.

\section{Simpati}

Berdasarkan hasil penelitian dan pembahasan maka dapat disimpulkan bahwa: 1). Perlu diambil kebijakan dalam pelaksanaan program KIA ini dikarenakan pemerintah pusat menyatakan program KIA tidak diberlakukan secara serentak di seluruh wilayah Indonesia, melainkan hanya di daerah yang cakupan akta kelahiran bagi usia 0-17 tahun mencapai $75 \%$, sementara Kota Semarang pada tahun 2016 cakupan kepemilikan Akta Kelahiran baru mencapai $70 \%$. 2). Untuk itu dalam rangka pelaksanaan program KIA di tahun 2017 Pemerintah Daerah Kota Semarang menyiapkan serangkaian kebijakan persiapan, yakni: (a).Menerbitkan Perda No.4 Tahun 2016 tentang Administrasi Kependudukan. b)Mengumpulkan data jumlah penduduk dan data kepemilikan akta kelahiran dari anak-anak. Pemerintah menargetkan sebanyak 12.000 anak akan mendapat KIA dalam kurun waktu satu tahun yang akan diberikan pada anak usia 0-15 tahun dan diberikan secara serentak di 16 Kecamatan di Kota Semarang tanpa ada yang lebih diutamakan. Sedangkan kendala yang dialami Pemerintah Kota Semarang pada saat program KIA meliputi kendala non-hukum dan hokum. Kendala non-hukum meliputi : 1.) Ketidakjelasan serta terhambatnya pendistribusian blanko KIA dari pihak pusat ke daerah, 2.) Keterbatasan dan keterlambatanpemberian anggaran dari pusat; dan 3) kurangnya sumber daya manusia yang cukup kompeten untuk pengoperasian SIAK. Kendala hukum yang dialami adalah belum adanya peraturan pelaksana dari Perda Kota Semarang Nomor 4 Tahun 2016 Tentang Penyelenggaraan Administrasi Kependudukan.

Untuk mengatasi kendala tersebut upaya yang dilakukan oleh Pemerintah Daerah Kota Semarang adalah: Mempersiapkan pengadaan blanko KIA sendiri; Mempersiapkan sistem komputerisasi atau SIAK dan memberikan pelatihan pengoperasian SIAK terhadap para 
petugas; Membuat/merancang Peraturan Walikota sebagai pelaksana teknis dari Perda Kota Semarang No.4 Tahun 2016 Tentang Penyelenggaraan Administrasi Kependudukan. Agar program dapat terlaksana dengan tertib dan lancar penulis menyampaikan beberapa saran yaitu: a. Sosialisasi kepada masyarakat mengenai KIA dan dasar pengaturannya agar pelaksanaanya nanti menjadi lancar dan tertib.b.Pihak Disdukcapil Kota Semarang hendaknya menghubungi pihak pusat kembali dan mendiskusikan mengenai kejelasan pendistribusian blanko KIA. Selain itu bagi pihak yang bertanggung jawab mengenai anggaran untuk program KIA hendaknya segera menyelesaikan prosedur yang harus dilakukan sehingga anggaran bisa segera cair demi kelancaran pelaksanaan KIA.

\section{Daftar Pustaka}

Buku Pegangan Bidang Kependudukan, Lembaga Demografi Fakultas Ekonomi Universitas Indonesia, Jakarta, 1980

Buku Saku Pedoman Penyelenggaraan Pelayanan Pendaftaran Penduduk Dan Pencatatan Sipil Kabupaten Gunungkidul, Dinas Kependudukan dan Pencatatan Sipil Kabupaten Gunungkidul, Gunungkidul,2014.

Fajar Mukhti dan Achmad Yulianto, Dualisme Penelitian Hukum Normatif dan Empiris, Pustaka Pelajar, Yogyakarta, 2010.

Herni Srinurbayanti, Ronal Rofiandri, dan Wina Novitarini, Publikasi Hak Masyarakat dalam Bidang Identitas Cet 2, Pusat Studi Hukum dan Kebijakan Indonesia, Jakarta, 2003.

O’Donnell Dan, Perlindungan Anak; Sebuah panduan bagi Anggota Dewan Perwakilan Rakyat (terjemahan Agus Riyanto), Jakarta, 2006

Rahardjo Satjipto, Ilmu Hukum, PT. Citra Aditya Bakti, Bandung, 2010.

Rahayu, Hukum Hak Asasi Manusia, Badan Penerbit Universitas Diponegoro Semarang, Semarang,2015.

Ridwan Juniarso dan Sudrajat Sodik Achmad, Hukum Administrasi Negara dan Kebijakan Pelayanan Publik, Nuansa, Bandung, 2019.

Sinambela Lijan Poltak, dkk., Reformasi Pelayanan Publik; Teori, Kebijakan dan Implementasi, PT. Bumi Aksara, Jakarta,2006.

Soekanto Soejono, Pengantar Penulisan Hukum, UI-Press, Jakarta, 1982 Soemitro Ronny Hanitijo, Metodologi Penelitian Hukum \& Jurimetri, Ghalia Indonesia, Jakarta, 1990

Susanti Dyah Ochtarina dan Efendi A’an, Penelitian Hukum (Legal Research), Sinar Grafika, Jakarta,2015.

Waluyo Bambang, Penelitian Hukum Dalam Praktek, Sinar Grafika, Jakarta, 2002.

Warassih Esmi, Pranata Hukum Sebuah Telaah Sosiologis, Badan Penerbit Universitas Diponegoro, Semarang, 2011.

Undang-Undang No.23 Tahun 2006 Tentang Administrasi Kependudukan

Undang-Undang No.24 Tahun 2013 Tentang Perubahan Atas Undang-Undang No.23 Tahun 2006 Tentang Administrasi Kependudukan 
Undang-Undang No.35 Tahun 2014 tentang Perubahan Atas Undang-Undang No.23 Tahun 2002 tentang Perlindungan Anak.

Peraturan Menteri Dalam Negeri No.2 Tahun 2016 Tentang Kartu Identitas Anak

Peraturan Daerah Kota Semarang No. 12 Tahun 2008 Tentang Organisasi Tata Kerja Dinas Daerah Kota Semarang.

Peraturan Daerah Kota Semarang No.13 Tahun 2008 Tentang Organisasi Tata Kerja Lembaga Teknis Daerah dan Pelayanan Perijinan Terpadu Kota Semarang.

Peraturan Daerah Kota Semarang No.4 Tahun 2016 Tentang Penyelenggaraan Administrasi Kependudukan

Peraturan Walikota Semarang No. 29 Tahun 2008 Tentang Penjabaran Tugas dan Fungsi Dinas Kependudukan dan Catatan Sipil Kota Semarang.

Konvensi Hak-Hak Anak Perserikatan Bangsa-Bangsa Tahun 1989.

Deklarasi Universal Hak Asasi Manusia Tahun 1948.

Aryanti Elina. 2014. “ Implementasi Kebijakan Kependudukan Di Kabupaten Kuantan Singingi (Studi Kasus Pengurusan Akta Kelahiran Tahun 2012)" Dalam Jurnal Online Mahasiswa FISIP, Vol.1

Febrina Tria, 2015. " Implementasi Kebijakan Kependudukan (Studi Kasus Peraturan Daerah Nomor 2 Tahun 2012 tentang Retribusi Penggantian Biaya Cetak Kartu Tanda Penduduk dan Akta Catatan Sipil Tahun 2013)" Dalam Jurnal Online Mahasiswa Fisip. Vol.2.

Aulia Aziza Mei Erdani.2016. “ Pelaksanaan Peraturan Dalam Negeri Nomor 2 Tahun 2016 Tentang Kartu Identitas Anak" Dalam Jurnal Online Mahasiswa Fakultas Hukum Tahun 2016

Tim Pengkajian Sistem Pelayanan Administrasi Kependudukan,2002. Rumusan disampaikan dalam Rapat Koordinasi Pengkajian Sistem Pelayanan Administrasi Kependudukan, 29 Mei, Jakarta.

Zudan Arif Fakrulloh. 2016. Kebijakan Administrasi Kependudukan Dalam Pemenuhan Hak Anak Atas Identitas disampaikan dalam Rakor Penyiapan Bahan Laporan Implementasi Konvensi Hak Anak, 5 Oktober, Jakarta. 